\title{
Evaluation of Preventive Fungicide Applications for Fairy Ring Control in Golf Putting Greens and In Vitro Sensitivity of Fairy Ring Species to Fungicides
}

\author{
G. L. Miller, M. D. Soika, and L. P. Tredway, Department of Plant Pathology, North Carolina State University, Raleigh 27695
}

\begin{abstract}
Miller, G. L., Soika, M. D., and Tredway, L. P. 2012. Evaluation of preventive fungicide applications for fairy ring control in golf putting greens and in vitro sensitivity of fairy ring species to fungicides. Plant Dis. 96:1001-1007.

Fairy ring species induce symptoms on putting greens mostly indirectly, by modifying the soil physical or chemical properties. Therefore, preventive rather than curative fungicide applications may be more effective in managing fairy ring. Two field experiments were conducted on a creeping bentgrass research green to evaluate fairy ring control from preventive fungicide applications. A 3-year study investigated the optimal rate and soil temperature-based timing of a preventive application of triadimefon and tebuconazole. A 2-year study evaluated the impact of irrigation timing and fungicide + surfactant tank mixtures on the efficacy of preventive applications of triadimefon and triticonazole. Fungicide-treated plots in both studies exhibited less

fairy ring severity than untreated plots. Data suggest that a 5-day average soil temperature range of 13 to $16^{\circ} \mathrm{C}$ may be suitable for initiating preventive applications. Symptoms occurred earlier in plots treated with a surfactant tank mix than in those treated with fungicide alone. Irrigation timing had no effect on fungicide performance. The sensitivity of 16 isolates representing major fairy ring species to flutolanil, propiconazole, tebuconazole, triadimefon, and triticonazole was determined with a mycelial growth assay. No significant differences in fungicide sensitivity were detected among species. Isolates had significantly higher $50 \%$ effective concentration values for triadimefon than for the other fungicides tested.
\end{abstract}

Fairy rings are a severe disease problem on golf courses and other highly maintained turf areas. The most commonly used grasses on golf courses in the United States are turf types of creeping bentgrass (Agrostis palustris Huds.) and hybrid bermudagrass (Cynodon dactylon $\times$ C. transvaalensis Burtt-Davy), which are bred for tolerance to low mowing heights (3). Fairy ring species can cause severe damage on both of these grasses, especially on putting greens. Most putting greens are constructed with a majority sand-based root zone, and the turf in these areas are under the most stress due to frequent mowing at low cutting heights.

Fairy ring symptoms appear along the outer margin of a developing subsurface fungal colony, where the density of mycelium is greatest (30). Rings can exhibit three types of symptoms, and one, two, or all three of these types can be observed in an affected area $(29,33)$. The most severe symptom (type I) leaves necrotic bands of turf from 10 to $30 \mathrm{~cm}$ wide and up to 4.5 to $9 \mathrm{~m}$ in diameter $(5,29)$. These necrotic bands are most commonly an artifact of drought-stressed turf, caused by a combination of dense fungal mycelium and the production of organic acids that coat sand particles and render the underlying soil hydrophobic $(2,12,39)$. A second symptom is the stimulation of lush green turf growth in rings or arcs (type II) caused by release of plant available nitrogen $(13,25,29)$. Ammonia levels may reach toxic levels, contributing to plant mortality $(9,30)$. Fairy rings may also produce circles of basidiocarps (type III), which have no direct effect on turf health but can negatively effect the aesthetic appearance of a turf area $(29,33)$

Fungicides that target basidiomycetes, such as flutolanil, azoxystrobin, and pyraclostrobin, have been found most effective for curative fairy ring control $(10,18,19,35)$. Curative suppression with these fungicides has been marginally efficient due to the water-repellent nature of the infested soil $(5,31,32)$. Therefore, for curative applications, mixing fungicides with soil surfactants and

Corresponding author: G. L. Miller, E-mail: turfpath@missouri.edu

Accepted for publication 2 February 2012.

http://dx.doi.org/10.1094/PDIS-09-11-0779-RE

(C) 2012 The American Phytopathological Society drenching with water are often necessary to deliver the fungicide to the target zone $(4,15,24)$. High-pressure injection of fungicides into the soil profile with specialized equipment has been investigated and found effective but has not been widely adopted due to high costs associated with the application $(1,11)$. Even with these methods, curative fairy ring control is not very effective because remediation of soil physical properties as well as pathogen suppression is necessary for turf recovery.

Nearly 60 different basidiomycete fungi have been implicated in fairy ring occurrence (5) but seldom is it known which fungus is responsible for a given outbreak of the disease on putting greens because routine mowing inhibits formation of a mature basidiocarp. Marasmius oreades is the most researched and most commonly named causal agent of fairy ring damage. However, in a recent study, Arachnion album Schwein., Bovista dermoxantha (Vittad.) De Toni, (= Lycoperdon dermoxanthum Vittad.), and Vascellum curtisii (Berk.) Kreisel (= L. curtisii Berk.) were more commonly observed in association with type I and type II fairy ring symptoms on sand-based putting greens in the southeast United States (23). The different fungi involved could differ in their sensitivity to fungicides, resulting in inconsistencies in product performance across locations.

Preventive fungicide applications are a standard control strategy for many soilborne turfgrass diseases (5). Despite the erratic nature and problems associated with curative fungicide applications, a preventive fungicide program for fairy ring control has not been investigated fully. In North Carolina, previous reports suggest significant fairy ring control with two low-rate preventive applications of the demethylation inhibitor (DMI) fungicides myclobutanil, metconazole, tebuconazole, triadimefon, and triticonazole $(21,38)$.

Few studies have used in vitro growth assays to assess the sensitivity of fairy ring fungi to fungicides. In 1973, Dale used in vitro sensitivity assays to identify alternatives to cadmium and mercurybased fungicides for control of fairy rings caused by $L$. perlatum Pers. (6). In vitro assays were also used to determine the effect of benomyl on the growth of unknown basidiomycete fungi causing superficial fairy rings $(6,14)$. The in vitro sensitivity of fairy ring pathogens to modern fungicides has not been investigated.

The purpose of this research was to investigate the influence of various application strategies on the performance of DMI fungicides for preventive fairy ring control. The specific objectives were 
to (i) evaluate the impact of application timing and fungicide rate on fairy ring control, (ii) investigate the influence of irrigation timing and soil surfactant tank mixtures on fungicide performance (iii), and compare the in vitro sensitivity of some common fairy ring species to fungicides.

\section{Materials and Methods}

Site description. Field experiments were conducted at the Lake Wheeler Turfgrass Field Laboratory in Raleigh, NC on a 'Penn A-1' creeping bentgrass research green. The plot was constructed in 2005 according to United States Golf Association specifications (3) with a root zone mix of $85 \%$ sand and $15 \%$ sphagnum peat moss by volume. In 2007, the plot area was found to be naturally infested with fairy rings caused by $V$. curtisii (Berk.) Kreisel; however, A. album Schwein. was also identified from infested soil and basidiocarps in 2009 (20). The green was fertilized with nitrogen at $317 \mathrm{~kg} \mathrm{ha}^{-1}$ in $2007,366 \mathrm{~kg} \mathrm{ha}^{-1}$ in 2008 , and $292 \mathrm{~kg} \mathrm{ha}^{-1}$ in 2009. Mowing was performed five times per week at $3.5 \mathrm{~mm}$ during the fall and spring and at 4.0 to $4.5 \mathrm{~mm}$ during the summer. The experimental area was aerified in the spring and fall with $1.6-\mathrm{cm}-$ diameter tines set at $3.8-$ to $5.1-\mathrm{cm}$ spacing. The fungicides chlorothalonil, fosetyl-Al, iprodione, and boscalid, which are not known to affect fairy ring, were applied for prevention of common foliar diseases. The study site was irrigated as needed to prevent drought stress.

Identification of optimal application rate and timing. A 3year field experiment (experiment 1) was initiated in 2007 to determine the optimal rate and soil temperature-based timing of triadimefon and tebuconazole applications for fairy ring prevention. Plots were 1.5 by $3 \mathrm{~m}$, with treatments arranged in a splitblock randomized complete block design with application timing as the main plot and fungicide as the subplot. Plots were not rerandomized between trial years in an effort to assess the multiyear impact of the treatments. Treatments were initiated in the spring from early March to late May when 5-day average soil temperatures reached $10,13,16,18,21$, or $23^{\circ} \mathrm{C}$. Soil temperatures were collected daily with a Watchdog data logger (Spectrum Technologies, Plainfield, IL) with an external soil probe located $5 \mathrm{~cm}$ below the soil surface. Fungicide treatments included a low and high labeled product rate of triadimefon $\left(0.15 \mathrm{~g}\right.$ and $0.30 \mathrm{~g}$ a.i. $\mathrm{m}^{-2}$, respectively) and tebuconazole $\left(0.08 \mathrm{~g}\right.$ and $0.15 \mathrm{~g}$ a.i. $\mathrm{m}^{-2}$, respectively), and an untreated control. Treatments were applied with a $\mathrm{CO}_{2}$-powered boom sprayer at $276 \mathrm{kPa}$ using flat fan nozzles (TeeJet 8004; TeeJet Technologies, Spraying Systems Company, Wheaton, IL) calibrated to deliver $\mathrm{H}_{2} \mathrm{O}$ at $81.5 \mathrm{ml} \mathrm{m}^{-2}$. No wetting agents were tank mixed with these applications but the soil surfactant Cascade Plus (Precision Laboratories Inc., Waukegan, IL) was applied at $1.27 \mathrm{ml} \mathrm{m}^{-2}$ separately every 28 days to reduce localized dry spot, a randomly occurring drought stress condition associated with hydrophobic soils.

Influence of irrigation timing and fungicide + surfactant tank mixtures. A 2-year field experiment (experiment 2) was initiated in 2008 to examine the impact of irrigation timing and fungicide + surfactant tank mixtures on the performance of preventive DMI applications. Plots were 1.5 by $3 \mathrm{~m}$, with treatments arranged in a split-block randomized complete block design with fungicide as the main plot and irrigation timing and surfactant tank mix as subplots. Plots were not re-randomized between trial years in an effort to assess the multiyear impact of the treatments. Fungicide treatments included a single rate of triadimefon $\left(0.15 \mathrm{~g}\right.$ a.i. $\left.\mathrm{m}^{-2}\right)$ and triticonazole $\left(0.08 \mathrm{~g}\right.$ a.i. $\left.\mathrm{m}^{-2}\right)$ and an untreated control. Fungicides were applied with a $\mathrm{CO}_{2}$-powered boom sprayer at $276 \mathrm{kPa}$ using flat fan nozzles (TeeJet 8008; R\&D Sprayers, Opelousas, LA) calibrated to deliver $\mathrm{H}_{2} \mathrm{O}$ at $81.5 \mathrm{ml} \mathrm{m}^{-2}$. Irrigation timing treatments included hand watering with $6.4 \mathrm{~mm}$ of irrigation either immediately or $10 \mathrm{~h}$ after the time of fungicide application. Fungicides were applied with or without the surfactant Revolution (Aquatrols, Paulsboro, $\mathrm{NJ}$ ) at a rate of $1.86 \mathrm{ml} \mathrm{m}^{-2}$. No additional surfactants were applied to these plots during the experiment. Treatments were applied on 28 March and 25 April 2008 and 31
March and 28 April 2009. The 5-day average soil temperature at 5 $\mathrm{cm}$ in depth on the first application date of both years was between 13 and $16^{\circ} \mathrm{C}$.

Evaluation of fairy ring severity. Disease severity was evaluated every 7 to 14 days from May through September. Disease was assessed by measuring the length and width of fairy ring arcs to derive percent diseased plot area. Area under the disease progress curve (AUDPC) was calculated with the formula $\Sigma\left[\left(y_{i}+y_{i+1}\right) / 2\right]\left[t_{i+1}\right.$ $-t_{i}$ ], where $i=1,2,3, \ldots, n-1, y_{i}$ is the percent diseased plot area, and $t_{i}$ is the time of the $i$ th rating (28). The ability of treatments to delay the expression of fairy ring symptoms was assessed by expressing the date of initial disease observation $\left(\mathrm{T}_{i}\right)$ in Julian days. Turfgrass quality was assessed visually by estimating the overall uniformity, density, and color within each plot after each fungicide application and during each disease severity rating. Turfgrass quality was quantified using a 1-to- 9 scale $(9=$ best, $5=$ minimally acceptable, and $1=$ bare ground).

For both studies, statistical analyses were conducted using SAS (version 9.1; SAS Institute, Cary, NC). Disease severity values were square root transformed prior to analysis. Least square means (LSMeans) for disease severity, AUDPC, and $\mathrm{T}_{i}$ were subjected to analysis of variance using the PROC MIXED procedure with year included as a fixed effect to determine whether data could be combined among the trial years. LSMeans were separated with the Tukey test $(\alpha=0.05)$. Untreated control treatments were removed from the data set for analyses of application timing in experiment 1 and from the data set for analyses of irrigation timing and surfactant tank mix in experiment 2.

In vitro sensitivity of fairy ring species to fungicides. Sixteen isolates representing the most common fairy ring species in a previous survey (20) were selected for in vitro fungicide sensitivity analyses. Prior to use, isolates were stored on sterilized filter paper maintained at $-80^{\circ} \mathrm{C}$. Hyphal plugs $(6 \mathrm{~mm}$ in diameter) from actively growing colonies on Leonian agar $(17,36)$ were placed in the center of petri dishes containing Leonian agar amended with nine concentrations $(0,0.002,0.006,0.02,0.06,0.2,0.6,2$, and $20 \mu \mathrm{g}$ a.i. $\mathrm{ml}^{-1}$ ) of technical grade formulations of flutolanil (Bayer CropScience, RTP, NC), propiconazole (Syngenta Crop Protection, Greensboro, NC), tebuconazole (Bayer CropScience, RTP), triadimefon (Bayer CropScience, RTP, NC), and triticonazole (Bayer CropScience, RTP) dissolved in acetone. Fungicide solutions were added to autoclaved potato dextrose agar cooled to $53^{\circ} \mathrm{C}$, such that the final concentration of acetone was $0.1 \%(\mathrm{vol} / \mathrm{vol})$ in all treatments, including the nonamended control.

Cultures were incubated at $30^{\circ} \mathrm{C}$ in the dark, and radial growth of colonies was measured when colony diameters of controls reached at least $40 \mathrm{~mm}$. Faster-growing isolates, such as Marasmius spp. or Coprinus spp., were measured 7 or 14 days after incubation, respectively. All other isolates were incubated for 28 days before measurement. The diameter of each colony was measured in two perpendicular directions and the mean diameter was adjusted by subtracting the diameter of the plug. Relative growth $(\mathrm{RG}=[$ the mean adjusted colony diameter on fungicide amended medium/mean adjusted colony diameter on nonamended medium] $\times$ 100) was determined for each isolate and fungicide concentration. Each fungicide-isolate combination was repeated twice and the entire experiment was repeated twice.

The $50 \%$ effective concentration $\left(\mathrm{EC}_{50}\right)$ value for each replication of each isolate was estimated by linear regression of the probit-transformed relative inhibition value $(\mathrm{RI}=1-\mathrm{RG})$ on $\log _{10^{-}}$ transformed fungicide concentration (22). The $\mathrm{EC}_{50}$ value for each isolate was calculated as the mean of the two replicates. Differences in $\mathrm{EC}_{50}$ values among isolates and species were determined using analysis of variance (ANOVA), and means were separated using the Tukey test $(\alpha=0.05)$. Assay consistency was determined by adding the experiment as a fixed effect in the ANOVA analysis.

\section{Results}

In 2007, type I and II symptoms were first observed in late May just prior to the $23^{\circ} \mathrm{C}$ application, making this a curative treatment 

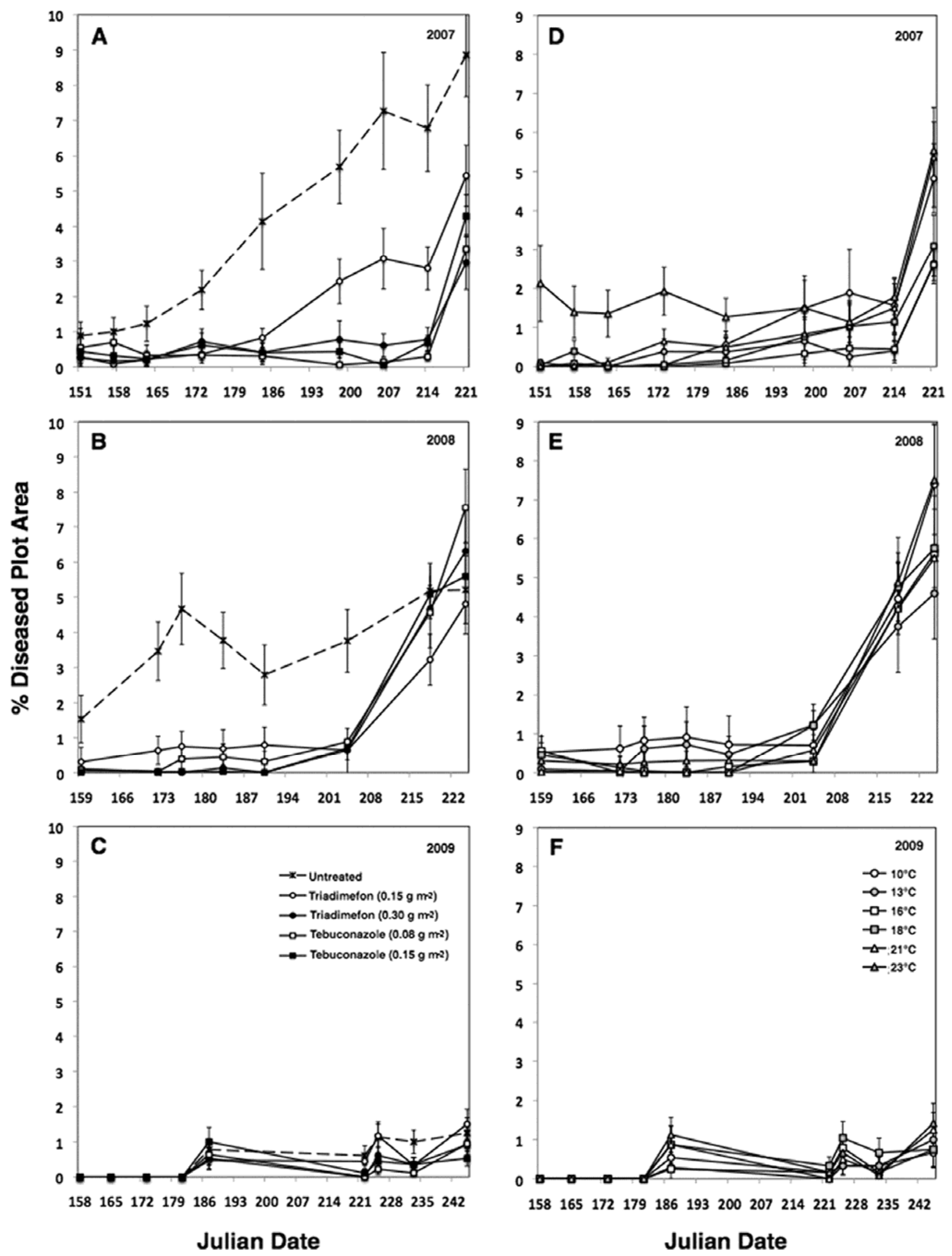

Fig. 1. Mean percent plot area with fairy ring symptoms on a creeping bentgrass putting green in response to a single fungicide application and application timing. A-C, Single fungicide application, 2007 to 2009. Data are averaged across all application timing treatments. D-F, Application timing, 2007 to 2009. Fungicides were applied each spring when 5day average soil temperatures taken at $5-\mathrm{cm}$ depth reached $10,13,16,18,21$, or $23^{\circ} \mathrm{C}$. Data are averaged across all fungicide treatments, and untreated control values are removed from the data set. Disease severity was assessed by measuring the length and width of fairy ring arcs to derive percent diseased plot area. Severity data were square-root transformed prior to analysis, with actual means shown. Plots were not re-randomized between years. Error bars represent the standard error of the mean. 
in 8 of the 20 total plots. In 2008 and 2009, type II fairy ring symptoms developed in the experimental areas in mid-June and midJuly, respectively, and were not present in the experimental area during the treatment periods. In both field experiments, disease severity decreased over the years of the study $(P<0.0003)$. In experiment 1, AUDPC values were equivalent in 2007 and 2008 and significantly decreased in 2009. In experiment 2, AUDPC values also significantly decreased in 2009 . Because data were different among the years $(P<0.0001$ and $P=0.0002$ for experiments 1 and 2 , respectively), each year was analyzed separately.

Application rate and timing. Plots treated with both rates of tebuconazole and the high rate of triadimefon had lower disease severity in 2007 and 2008 compared with the untreated control (Fig. 1). The low rate of triadimefon provided reduction in disease severity in both years but was not statistically different from the control in 2007. AUDPC values were lowest in plots sprayed at the 13 and $16^{\circ} \mathrm{C}$ soil temperature thresholds but were not statistically different from any other application timing. Similarly, the date of initial disease observation $\left(\mathrm{T}_{i}\right)$ was not statistically different among soil-temperature-based application timings (Table 1). Grayishbrown turf discoloration was observed in plots treated with triadimefon in early June 2008, resulting in a decrease in overall turf quality compared with plots treated with tebuconazole $(P=0.004)$. Triadimefon-treated plots recovered by mid-June, and overall turf quality ratings did not fall below acceptable levels $(<5)$. Disease severity was low in the plot area in 2009 (Fig. 1), and no significant differences were found among treatments.

Surfactant tank mix and irrigation timing. Fairy ring symptoms became evident in the experimental area in mid-June 2008 and mid-July 2009. Plots treated with two low-rate applications of triadimefon or triticonazole had significantly lower AUDPC values compared with untreated controls in both 2008 and 2009, and significantly delayed the onset of symptoms in 2008 (Table 2). No differences were detected in the level of control afforded by either fungicide. Irrigation timing did not impact the efficacy of fungicide applications in either year. Although not statistically significant in either year, AUDPC values were higher in plots that received a fungicide + surfactant tank mix as opposed to fungicide alone. In 2009 , fairy ring symptoms were observed significantly earlier in plots that were treated with a fungicide + surfactant tank mix than those applied with a fungicide alone (Fig. 2). As in experiment 1, turfgrass quality was significantly lower in plots treated with triadimefon in 2008 than tebuconazole-treated plots due to grayishbrown discoloration observed in early June $(P=0.0429)$. Triadime-

Table 1. Influence of a single fungicide treatment and application timing on fairy ring severity and date of initial symptom observation in experiment $1^{\mathrm{v}}$

\begin{tabular}{|c|c|c|c|c|c|c|}
\hline \multirow[b]{2}{*}{ Treatment } & \multicolumn{3}{|c|}{ AUDPC $^{w}$} & \multicolumn{3}{|c|}{$\mathbf{T}_{i}^{\mathbf{x}}$} \\
\hline & 2007 & 2008 & 2009 & 2007 & 2008 & 2009 \\
\hline \multicolumn{7}{|l|}{ Fungicide } \\
\hline Untreated & $359 \mathrm{a}$ & $301 \mathrm{a}$ & $61.4 \mathrm{a}$ & $182 \mathrm{~b}$ & $186 \mathrm{~b}$ & $229 \mathrm{a}$ \\
\hline Triadimefon $\left(0.15 \mathrm{~g} \mathrm{~m}^{-2}\right)$ & $154 \mathrm{ab}$ & $136 \mathrm{~b}$ & $46.8 \mathrm{a}$ & $195 \mathrm{ab}$ & $210 \mathrm{a}$ & $232 \mathrm{a}$ \\
\hline Triadimefon $\left(0.30 \mathrm{~g} \mathrm{~m}^{-2}\right)$ & $83.6 \mathrm{~b}$ & $131 \mathrm{~b}$ & $31.1 \mathrm{a}$ & $212 \mathrm{a}$ & $220 \mathrm{a}$ & $240 \mathrm{a}$ \\
\hline Tebuconazole $\left(0.08 \mathrm{~g} \mathrm{~m}^{-2}\right)$ & $89.5 \mathrm{~b}$ & $144 \mathrm{~b}$ & $27.9 \mathrm{a}$ & $212 \mathrm{a}$ & $216 \mathrm{a}$ & $241 \mathrm{a}$ \\
\hline Tebuconazole $\left(0.15 \mathrm{~g} \mathrm{~m}^{-2}\right)$ & $96.9 \mathrm{~b}$ & $125 \mathrm{~b}$ & $40.1 \mathrm{a}$ & $212 \mathrm{a}$ & $222 \mathrm{a}$ & $231 \mathrm{a}$ \\
\hline \multicolumn{7}{|l|}{ Application timing ${ }^{\mathrm{z}}$} \\
\hline $10^{\circ} \mathrm{C}$ & $108 \mathrm{~b}$ & $155 \mathrm{a}$ & $30.9 \mathrm{a}$ & $210 \mathrm{~b}$ & $212 \mathrm{a}$ & $239 a$ \\
\hline $13^{\circ} \mathrm{C}$ & $72.3 \mathrm{~b}$ & $122 \mathrm{a}$ & $24.6 \mathrm{a}$ & $219 \mathrm{~b}$ & $219 \mathrm{a}$ & $242 \mathrm{a}$ \\
\hline $16^{\circ} \mathrm{C}$ & $60.1 \mathrm{~b}$ & $120 \mathrm{a}$ & $26.4 \mathrm{a}$ & $219 \mathrm{~b}$ & $216 \mathrm{a}$ & $241 \mathrm{a}$ \\
\hline $18^{\circ} \mathrm{C}$ & $71.7 \mathrm{~b}$ & $148 \mathrm{a}$ & $48.9 \mathrm{a}$ & $216 \mathrm{~b}$ & $216 \mathrm{a}$ & $231 \mathrm{a}$ \\
\hline $21^{\circ} \mathrm{C}$ & $119 \mathrm{~b}$ & $111 \mathrm{a}$ & $38.4 \mathrm{a}$ & $209 \mathrm{~b}$ & $225 \mathrm{a}$ & $238 a$ \\
\hline $23^{\circ} \mathrm{C}$ & $205 \mathrm{a}$ & $149 \mathrm{a}$ & $49.7 \mathrm{a}$ & $175 \mathrm{a}$ & $214 \mathrm{a}$ & $223 \mathrm{a}$ \\
\hline
\end{tabular}

${ }^{\mathrm{v}}$ Data are least square means of four replications (plots). Values followed by the same letter within a column are not significantly different according to Tukey test $(\alpha=0.05)$.

${ }^{w}$ Disease severity was assessed by measuring the length and width of fairy ring arcs to derive percent diseased plot area. Area under the disease progress curve (AUDPC) was calculated as in Shaner and Finney (28).

${ }^{\mathrm{x}} \mathrm{T}_{i}=$ average Julian date of initial symptom observation.

${ }^{y}$ Data averaged across all application timings.

${ }^{\text {z }}$ Data averaged across fungicide treatments. Values for untreated control plots were removed for least square mean calculation and data analysis.

Table 2. Influence of fungicide treatment, irrigation timing, and surfactant tank mix on fairy ring severity and date of initial symptom observation in experiment $2^{\mathrm{v}}$

\begin{tabular}{|c|c|c|c|c|}
\hline \multirow[b]{2}{*}{ Treatment } & \multicolumn{2}{|c|}{ AUDPC $^{w}$} & \multicolumn{2}{|c|}{$\mathbf{T}_{i}^{\mathbf{x}}$} \\
\hline & 2008 & 2009 & 2008 & 2009 \\
\hline \multicolumn{5}{|l|}{ Fungicide $^{y}$} \\
\hline Untreated & 418 a & $166 \mathrm{a}$ & $195 \mathrm{~b}$ & $217 \mathrm{a}$ \\
\hline Triadimefon $\left(0.15 \mathrm{~g} \mathrm{~m}^{-2}\right)$ & $121 \mathrm{~b}$ & $63 \mathrm{~b}$ & 227 a & $233 \mathrm{a}$ \\
\hline Triticonazole $\left(0.08 \mathrm{~g} \mathrm{~m}^{-2}\right)$ & $99.5 \mathrm{~b}$ & $67 \mathrm{~b}$ & $234 \mathrm{a}$ & $232 \mathrm{a}$ \\
\hline \multicolumn{5}{|l|}{ Irrigation timing ${ }^{\mathrm{z}}$} \\
\hline Immediate & $125 \mathrm{a}$ & $74.6 \mathrm{a}$ & $226 \mathrm{a}$ & $231 \mathrm{a}$ \\
\hline $10 \mathrm{~h}$ post application & $95.4 \mathrm{a}$ & $55.1 \mathrm{a}$ & $235 \mathrm{a}$ & $233 \mathrm{a}$ \\
\hline \multicolumn{5}{|l|}{ Surfactant tank mix } \\
\hline None & $98.3 \mathrm{a}$ & $54.1 \mathrm{a}$ & $231 \mathrm{a}$ & $242 \mathrm{a}$ \\
\hline + Revolution (1.86 $\left.\mathrm{ml} \mathrm{m}^{-2}\right)$ & $121.7 \mathrm{a}$ & $75.6 \mathrm{a}$ & $229 \mathrm{a}$ & $223 \mathrm{~b}$ \\
\hline
\end{tabular}

${ }^{\mathrm{v}}$ Data are least square means of four replications (plots). Values followed by the same letter within a column are not significantly different according to Tukey test $(\alpha=0.05)$.

${ }^{w}$ Disease severity was assessed by measuring the length and width of fairy ring arcs to derive percent diseased plot area. Area under the disease progress curve calculated as in Shaner and Finney (28).

${ }^{\mathrm{x}} \mathrm{T}_{i}=$ average Julian date of initial symptom observation.

${ }^{\mathrm{y}}$ Data averaged across irrigation timing and surfactant tank mix treatments.

${ }^{\mathrm{z}}$ Data for irrigation timing and surfactant tank mix treatments were averaged across fungicide treatments. Values for untreated control plots were removed for least square mean calculation and data analysis. 
fon-treated plots recovered quickly from the phytotoxic effect and overall turf quality was acceptable $(>5)$. Due to development of localized dry-spot symptoms in both years, plots not treated with a surfactant had a significantly lower turf quality $($ LSMean $=5.5)$ than those that received a surfactant (LSMean $=6.2$ ), according to the Tukey test $(\alpha=0.05)$.

In vitro sensitivity of fairy ring fungi to fungicides. Significant differences in $\mathrm{EC}_{50}$ values were not detected between the two experiments $(P=0.759)$; therefore, the average of the two $\mathrm{EC}_{50}$ values was used for analysis (Table 3 ). Significant differences in $\mathrm{EC}_{50}$ values were detected among isolates within the same species (Table 3). No differences in fungicide sensitivity were detected among species $(P=0.449)$. Differences in sensitivity of isolates were detected among fungicides. Isolates were most sensitive to tebuconazole $\left(\mathrm{EC}_{50}=0.149 \mu \mathrm{g} / \mathrm{ml}\right)$ and triticonazole $\left(\mathrm{EC}_{50}=0.263\right.$ $\mu \mathrm{g} / \mathrm{ml})$, moderately sensitive to propiconazole $\left(\mathrm{EC}_{50}=0.371\right.$ $\mu \mathrm{g} / \mathrm{ml})$ and flutolanil $\left(\mathrm{EC}_{50}=0.546 \mu \mathrm{g} / \mathrm{ml}\right)$, and least sensitive to triadimefon $\left(\mathrm{EC}_{50}=0.821 \mu \mathrm{g} / \mathrm{ml}\right)$.

\section{Discussion}

This study demonstrates the efficacy of using certain DMI fungicides for preventive fairy ring control, reducing the need for more numerous and costly curative fungicide applications and soil remediation procedures. When turf loss occurs, the fairy ring pathogen imparts a hydrophobic condition on the soil, rendering delivery of curative fungicide applications difficult. Because of this, cultivation and surfactant application are also necessary to encourage turf recovery. Few previous studies have investigated the efficacy of preventive fungicide applications. Elliot et al. (8) found that four preventive applications of flutolanil applied at a 6-week interval provided protection against fairy ring occurrence caused by a Lycoperdon spp.

Proper timing of preventive applications is necessary to maximize the residual effectiveness of the fungicide and target a vulnerable portion of the pathogen's life cycle. Because truly preventive applications are made before plant symptoms are evident, environ-

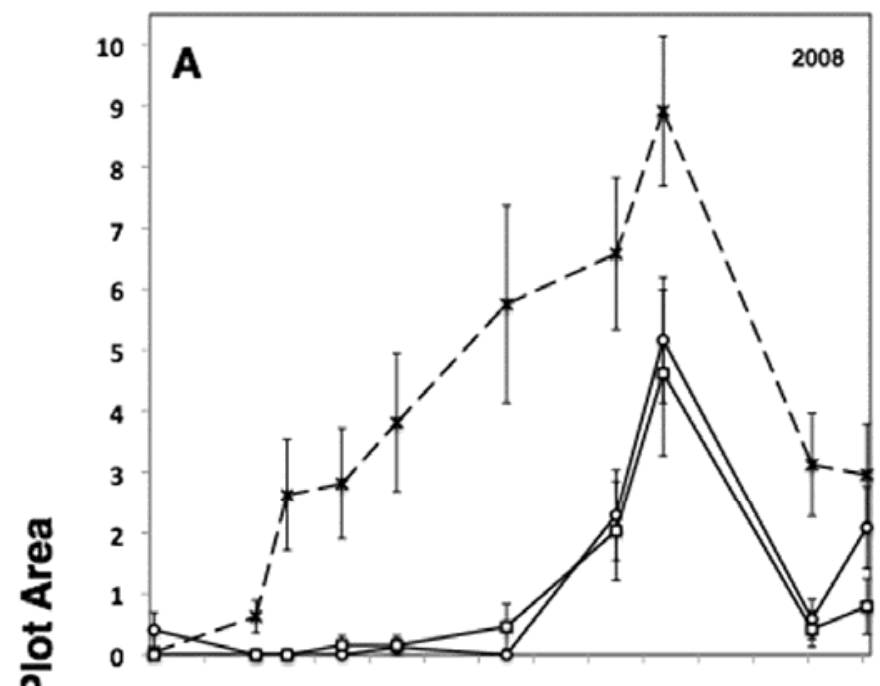

159166173180187194201208215222229236243250

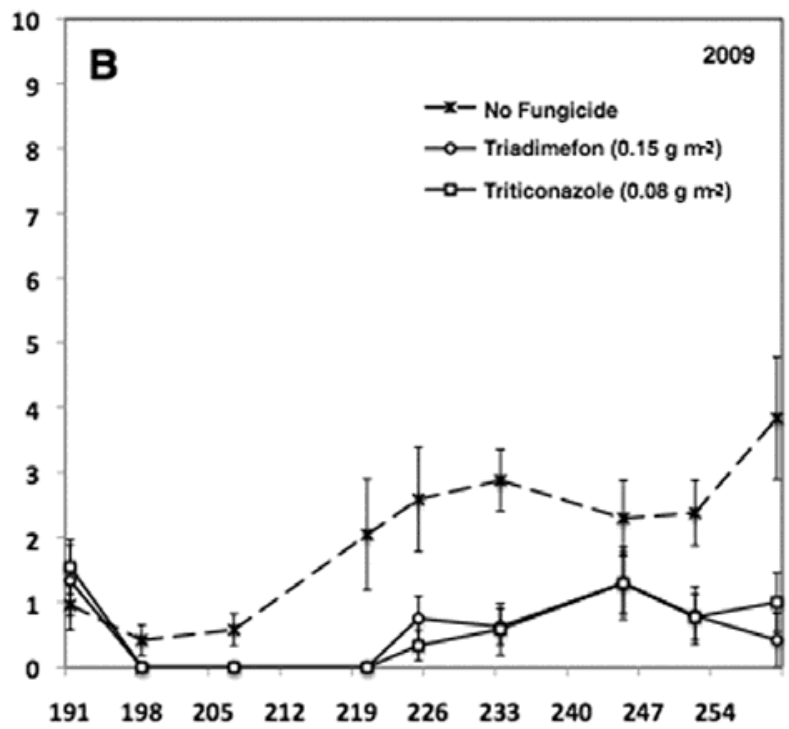

Julian Date

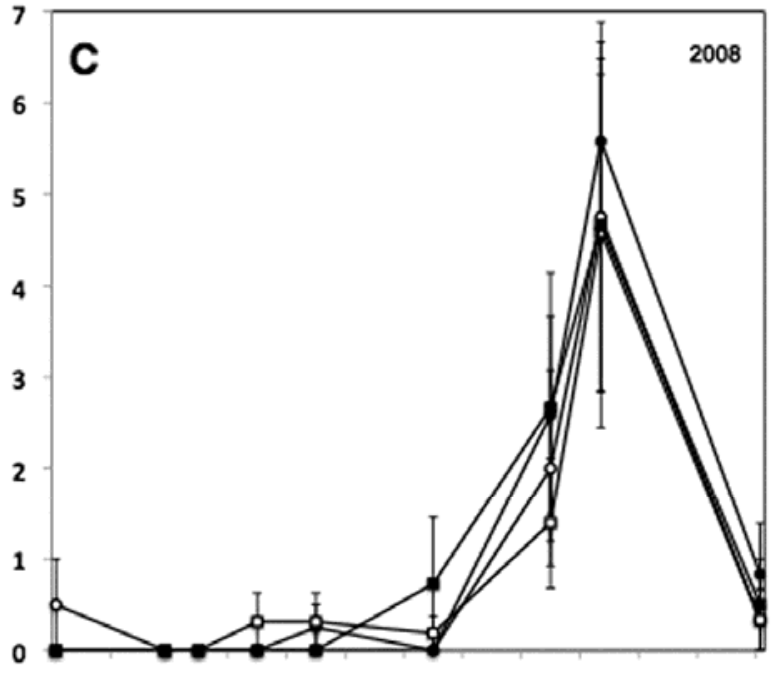

$\begin{array}{lllllllllllll}159 & 166 & 173 & 180 & 187 & 194 & 201 & 208 & 215 & 222 & 229 & 236 & 243\end{array}$

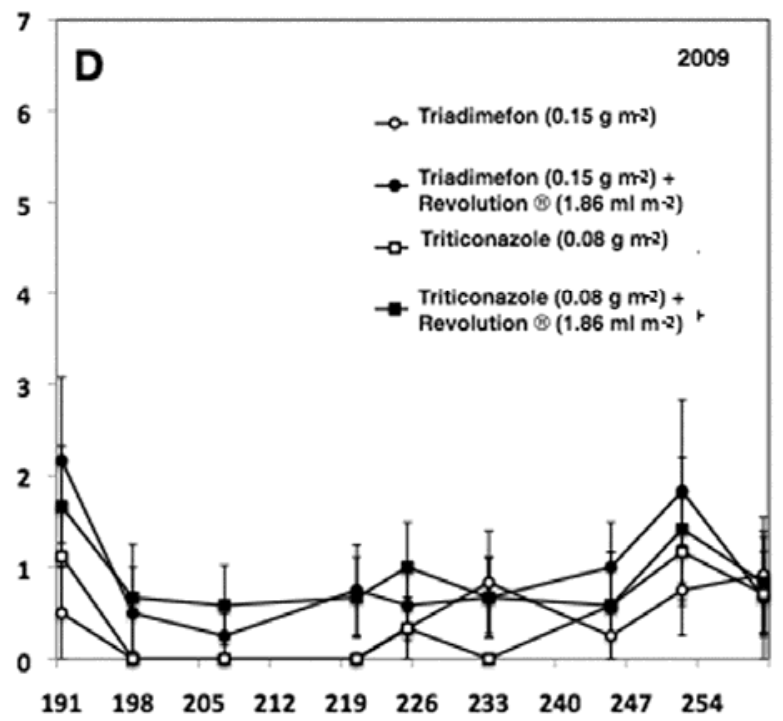

Julian Date

Fig. 2. Mean percent plot area with fairy ring symptoms on a creeping bentgrass putting green in response to preventive fungicide applications and surfactant tank mix. A-C, Two fungicide applications (2008 and 2009) were applied at a 28-day interval in late March (average soil temperature at 5 -cm depth $=13^{\circ} \mathrm{C}$ ) and late April of both years. Data are averaged across irrigation timing and surfactant tank mix treatments. D-F, Fungicides with or without a surfactant (2008 and 2009). Data are averaged across all irrigation timing treatments, and untreated control values are removed from the data set. Disease severity was assessed by measuring the length and width of fairy ring arcs to derive percent diseased plot area. Severity data were square-root transformed prior to analysis, with actual means shown. Plots were not re-randomized between years. Error bars represent the standard error of the mean. 
mental cues, such as soil temperature, have been used as indicators of application timing for control of soilborne turf pathogens (16). Statistical determination of a most effective soil temperature threshold for fairy ring prevention was not achieved in this field study. A weak data trend suggests that preventive applications made at 5-day soil temperature averages of 13 or $16^{\circ} \mathrm{C}$ may be efficacious but further study should be conducted to confirm this result.

Due to the difficulty of traditional morphological identification, fairy ring control studies on high-amenity turfgrasses are often conducted without the speciation of the causal agent. This lack of specificity is problematic because different species may contribute to the observed variation in the efficacy of control practices. At this experimental site, the fairy ring species was determined to be $V$. curtisii in 2007; however, puffballs of A. album were associated with symptoms in 2009 (20). No differences in fungicide sensitivity were detected between these two fairy ring species with the in vitro assay used in this study. However, only one to seven isolates were used to represent each species in this study; therefore, this result should be confirmed with future testing.

No differences in field efficacy were detected among the DMI fungicides tested in this study. This is in contrast to the results of our in vitro assay, which indicate a biological difference in the toxicity of triadimefon, triticonazole, and tebuconazole to the fairy ring species present in the experimental area. Triadimefon would be expected to provide the least amount of control if pathogen sensitivity was the primary factor determining field efficacy. However, triadimefon has been shown to strongly adsorb to soil $(\mathrm{Kd}=$ 19.4 liters per kilogram of soil) and slowly breaks down into triadimenol, a soluble fungicidal active ingredient (27). The longer soil residual and sustained biological activity may be responsible for the effectiveness of triadimefon in fairy ring prevention.

Fungicide application methods may also impact the efficacy and duration of preventive control. Other surfactant chemistries may respond differently but data in this research suggests that tank mixing a surfactant with a preventive fungicide does not result in increased disease control. This is in direct contrast to a curative situation, where fungicides must be tank mixed with a surfactant to aid delivery of the material through the hydrophobic layer and into the target zone of the soil profile. Because hydrophobicity is not present in a preventive situation, the surfactant may diminish the soil residual of the fungicide and, therefore, reduce its efficacy.

DMI fungicides often exhibit plant-growth-regulating properties due to reducing the formation of $14 \alpha$-demethylated sterols by blocking obtusifoliol 14 $\alpha$-demethylase (37). Phytotoxicity can result in some turfgrasses, particularly when the DMI fungicides are applied during high-temperature periods $(7,34)$. Applying in the spring, watering the fungicide in, and using lower rates should diminish the phytotoxic effect that is normally attributed to hightemperature applications of the DMI fungicides. In a high-temperature period in early June, (maximum air temperatures $>32^{\circ} \mathrm{C}$ ), we did observe slight phytotoxicity associated with preventive triadimefon applications that affected the color and quality of creeping bentgrass. Future research should also assess the impact of preventive DMI applications on spring green-up of bermudagrass, and the transition from a cool-season turf species utilized during the winter months to a warm-season turf species.

Due to the erratic nature of fairy ring occurrence and the inability to inoculate and reproduce symptoms, very few fairy ring trials are replicated on the same site. Fairy ring severity significantly decreased across our experimental site over the years of our trial, potentially increasing the effects of variation and decreasing detectable differences among our treatments. Common experimental designs such as randomized complete block may be inadequate to properly evaluate fairy ring control practices in a multiyear experiment. Re-randomization of plots between years was not conducted in this trial to maintain the integrity of our controls. However, due to the significant difference between the years in our study, the data could not be combined and only differences within years could be assessed. Fairy rings move horizontally through the soil profile, with growth rates estimated to be 7 to 150 $\mathrm{cm}$ a year (5). Even at a conservatively low growth rate, there is potential for fairy ring fungi to migrate from a control plot to a treated plot and leave behind symptomless turf. Plot designs that leave an untreated area to serve as a reservoir for fairy ring inoculum may aid in reducing variability but may require too much area to be feasible. Although fairy ring appeared to be uniformly distributed across our trial area prior to initiating the field experiments, establishing a baseline with quantitative observations would have aided our statistical analyses. A baseline would have allowed higher-level spatial analysis such as the Covariate method, nearestneighbor adjustments, moving means, or the autoregressive method, which may have been necessary to reduce variability not accounted for by blocking in the experimental design (26).

Results from this and an earlier study (21) indicate that preventive low-rate applications of the DMI fungicides triadimefon, triticonazole, tebuconazole, metconazole, or myclobutanil are an effective tool in the suppression of fairy ring on putting greens caused by either $B$. dermoxantha or $V$. curtisii. These results are specific to sand-based putting greens and have not yet been evaluated for golf course tees, fairways, or other areas. For this reason, effectiveness may vary for fairy ring suppression caused by another species or

Table 3. In vitro sensitivity of fairy ring isolates to flutolanil, propiconazole, tebuconazole, triadimefon, and triticonazole

\begin{tabular}{|c|c|c|c|c|c|c|}
\hline \multirow[b]{2}{*}{ Isolate } & \multirow[b]{2}{*}{ Species $^{\mathrm{Z}}$} & \multicolumn{5}{|c|}{$\mathrm{EC}_{50}$ concentration $(\mu \mathrm{g} / \mathrm{ml})^{y}$} \\
\hline & & Flutolanil & Propiconazole & Tebuconazole & Triadimefon & Triticonazole \\
\hline $\mathrm{NCP} 2$ & Arachnion album & $0.321 \mathrm{~b}$ & $0.620 \mathrm{a}$ & $0.566 \mathrm{a}$ & $1.09 \mathrm{a}$ & $0.541 \mathrm{ab}$ \\
\hline NCP50 & A. album & $0.197 \mathrm{c}$ & $0.576 \mathrm{a}$ & $0.220 a b$ & $1.31 \mathrm{a}$ & $0.227 \mathrm{bc}$ \\
\hline SCP1 & A. album & $1.03 \mathrm{~b}$ & $0.150 \mathrm{a}$ & $0.162 a b$ & $0.487 \mathrm{a}$ & $0.061 \mathrm{c}$ \\
\hline CAP1 & Bovista dermoxantha & $0.243 b c$ & $0.230 \mathrm{a}$ & $0.100 \mathrm{ab}$ & $0.675 \mathrm{a}$ & $0.144 \mathrm{c}$ \\
\hline FLSB1 & B. dermoxantha & $0.650 \mathrm{bc}$ & $0.150 \mathrm{a}$ & $0.154 a b$ & $0.565 \mathrm{a}$ & $0.092 \mathrm{c}$ \\
\hline ILSB1 & B. dermoxantha & $0.699 \mathrm{bc}$ & $0.163 \mathrm{a}$ & $0.003 \mathrm{~b}$ & $0.680 \mathrm{a}$ & $0.173 \mathrm{bc}$ \\
\hline Lp3 & B. dermoxantha & $0.397 \mathrm{bc}$ & $0.517 \mathrm{a}$ & $0.053 \mathrm{ab}$ & $0.635 \mathrm{a}$ & $0.307 \mathrm{bc}$ \\
\hline NCP34 & B. dermoxantha & $0.155 \mathrm{c}$ & $0.329 \mathrm{a}$ & $0.225 \mathrm{ab}$ & $0.940 \mathrm{a}$ & $0.394 \mathrm{ab}$ \\
\hline NCP47 & B. dermoxantha & $0.210 \mathrm{bc}$ & $0.504 \mathrm{a}$ & $0.372 a b$ & $0.593 \mathrm{a}$ & $0.743 \mathrm{a}$ \\
\hline $\mathrm{SCP} 2$ & B. dermoxantha & $1.90 \mathrm{a}$ & $0.328 \mathrm{a}$ & $0.041 \mathrm{ab}$ & $0.871 \mathrm{a}$ & $0.732 \mathrm{a}$ \\
\hline OKSB1 & Coprinus sp. & $0.312 b c$ & $0.754 \mathrm{a}$ & $0.139 \mathrm{ab}$ & $0.975 \mathrm{a}$ & $0.216 b c$ \\
\hline NCSB2 & Marasmius sp. & $0.313 \mathrm{bc}$ & $0.519 \mathrm{a}$ & $0.164 a b$ & $1.49 \mathrm{a}$ & $0.109 \mathrm{c}$ \\
\hline HIP1 & Vascellum curtisii & $1.03 \mathrm{~b}$ & $0.185 \mathrm{a}$ & $0.003 \mathrm{~b}$ & $0.557 \mathrm{a}$ & $0.091 \mathrm{c}$ \\
\hline NCP24 & V. curtisii & $0.274 \mathrm{bc}$ & $0.468 \mathrm{a}$ & $0.152 a b$ & $0.539 \mathrm{a}$ & $0.241 \mathrm{bc}$ \\
\hline NCP31 & V. curtisii & $0.668 \mathrm{bc}$ & $0.217 \mathrm{a}$ & $0.003 \mathrm{~b}$ & $0.714 \mathrm{a}$ & $0.045 \mathrm{c}$ \\
\hline NCSB4 & V. curtisii & $0.334 \mathrm{bc}$ & $0.231 \mathrm{a}$ & $0.028 \mathrm{~b}$ & $1.01 \mathrm{a}$ & $0.086 \mathrm{c}$ \\
\hline Mean & $\ldots$ & $0.546 \mathrm{~b}$ & $0.371 \mathrm{bc}$ & $0.149 \mathrm{~d}$ & $0.821 \mathrm{a}$ & $0.263 \mathrm{~cd}$ \\
\hline
\end{tabular}

${ }^{\mathrm{y}} \mathrm{EC}_{50}=50 \%$ effective concentration. Values are the average of two experiments with two replicate plates per concentration per experiment. Values followed by the same letter within a column are not significantly different according to the Tukey test $(\alpha=0.05)$.

${ }^{\mathrm{z}}$ Fairy ring species identified by Miller et al. (21). 
for another soil type. Our in vitro studies suggest no biological differences among the five prominent fairy ring species to the fungicides tested but further research should confirm correlation of these results to field fungicide performance.

There is a high level of specificity to the observations made in this study, which centers on the causal agent and ecosystem and not a broadly defined plant symptom. Future research regarding fairy ring control strategies should also utilize recently outlined methods $(20,23)$ to identify the pathogen being investigated. This would allow for direct comparison with this and other fairy ring management research, and facilitate control recommendations that target the specific pathogen.

\section{Acknowledgments}

This research was supported by grants from Bayer Environmental Science, the Environmental Institute for Golf, Carolinas Association of Golf Course Superintendents, and the Center for Turfgrass Environmental Research and Education at North Carolina State University. We thank E. Rosebrough and A. Rosebrough (North Carolina State University) for valuable technical assistance.

\section{Literature Cited}

1. Baldwin, N. A. 1989. Technical note: application of fungicides to Marasmius oreades fairy rings with soil injection equipment. J. Sports Turf Res. Inst. 65:161-164.

2. Bayliss, J. S. 1911. Observations on Marasmius oreades and Clitocybe gigantea as parasitic fungi causing fairy rings. J. Econ. Biol. 6:111-132.

3. Beard, J. B. 1992. Turf Management for Golf Courses. Burgess Publishing Company, Minneapolis, MN.

4. Blenis, P. V., Nadeau, L. B., and Knowles, N. R. 1997. Evaluation of fungicides and surfactants for control of fairy rings caused by Marasmius oreades. HortScience 32:1077-1084.

5. Couch, H. B. 1995. Diseases of Turfgrasses. Krieger Publishing, Malabar, FL.

6. Dale, J. L. 1973. Inhibition of puffball growth by fungicides. Plant Dis. Rep. 57:711-712.

7. Elliott, M. L. 1995. Effect of systemic fungicides on a bermudagrass putting green infested with Gaeumannomyces gramins var. graminis. Plant Dis. 79:945-949.

8. Elliott, M. L., Hickman, R. B., and Hopkins, M. 2002. Flutolanil for control of necrotic fairy rings on bermudagrass putting greens. HortTechnology 12:656-659.

9. Fidanza, M. A. 2007. Characterization of soil properties associated with type-I fairy ring symptoms in turfgrass. Biologia 62:533-536.

10. Fidanza, M. A., and Bagwell, A. 2005. Evaluation of fungicides and a soil surfactant for curative type-II fairy ring control in creeping bentgrass, 2004. Fungic. Nematicide Tests 60:1.

11. Fidanza, M. A., Colbaugh, R., Engelke, M. C., Davis, S. D., and Kenworthy, K. E. 2005. Use of high-pressure injection to alleviate type-I fairy ring symptoms in turf grass. HortTechnology 15:169-172.

12. Fidanza, M. A., Schlossberg, M. J., Kostka, S. J., and Sanford, D. L. 2005. Soil hydrophobicity associated with type-I fairy ring in turfgrass. Geophys. Res. Abstr. 7:1-2.

13. Fisher, R. F. 1977. Nitrogen and phosphorus mobilization by the fairy ring fungus, Marasmius oreades (Bolt.) Fr. Soil Biol. Biochem. 9:239-241.

14. Kackley, K. E., Dernoeden, P. H., and Grybauskas, A. P. 1989. Effect of fungicides on the occurrence and growth in vitro of basidiomycetes associated with superficial fairy rings in creeping bentgrass. Plant Dis. 73:127130.

15. Karnok, K. J., and Tucker, K. A. 2001. Effects of flutolanil fungicide and primer wetting agent on water-repellent soil. HortTechnology 11:437-440.

16. Kerns, J. P., Soika, M. D., and Tredway, L. P. 2009. Preventive control of
Pythium root dysfunction in creeping bentgrass putting greens and sensitivity of Pythium volutum to fungicides. Plant Dis. 93:1275-1280.

17. Leonian, L. H. 1924. A study of factors promoting pycnidium-formation in some Sphaeropsidiales. Am. J. Bot. 11:19-50.

18. Martin, B. 1998. Evaluation of Heritage and Prostar for fairy ring suppression in creeping bentgrass, 1997. Fungic. Nematicide Tests 53:449.

19. Martin, S. B., Blake, J. H., and Goss, G. B., Jr. 1994. Suppression of fairy rings in turf with flutolanil. (Abstr.) Phytopathology 84:1065.

20. Miller, G. L., Grand, L. F., and Tredway, L. P. 2011. Identification and distribution of fungi associated with fairy rings on golf putting greens. Plant Dis. 95:1131-1138.

21. Miller, G. L., Soika, M. D., and Tredway, L. P. 2009. Evaluation of fungicides for preventive control of fairy ring caused by Lycoperdon pusillum on bermudagrass and creeping bentgrass putting greens, 2008. Plant Dis. Manage. Rep. 3:T058.

22. Miller, G. L., Stevenson, K. L., and Burpee, L. L. 2002. Sensitivity of Sclerotinia homoeocarpa isolates to propiconazole and impact on control of dollar spot. Plant Dis. 86:1240-1246.

23. Miller, G. L., Jr., and Tredway, L. P. 2009. Selective amplification of fairy ring fungi from infested putting green soils. Int. Turfgrass Soc. Res. J. 11:253-262.

24. Nadeau, L. B., Blenis, P. V., and Knowles, N. R. 1993. Potential of an organosilicone surfactant to improve soil wettability and ameliorate fairy ring symptoms caused by Marasmius oreades. Can. J. Plant Sci. 73:11891197.

25. Norstadt, F. A., Frey, C. R., and Sigg, H. 1973. Soil urease: paucity in the presence of the fairy ring fungus Marasmius oreades (Bolt.) Fr. Soil Sci. Soc. Am. Pro. 37:880-885.

26. Peiris, T. U. S., Samita, S., and Veronica, W. H. D. 2008. Accounting for spatial variability in field experiments on tea. Exp. Agric. 44:547-557.

27. Rawlinson, C. J., Muthyalu, G., and Cayley, G. R. 1982. Residual effects of triadimefon in soil on powdery mildew and yield of spring barley. Plant Pathol. 31:143-155.

28. Shaner, G., and Finney, R.E. 1977. The effect of nitrogen fertilization on the expression of slow-mildewing resistance in Knox wheat. Phytopathology 67:1051-1056

29. Shantz, H. L., and Piemesel, R. L. 1917. Fungus fairy rings in eastern Colorado and their effect on vegetation. J. Agric. Res. 11:191-245.

30. Smith, J. D. 1957 Fungi and turf diseases. 7: Fairy rings. J. Sports Turf Res. Inst. 33:324-352.

31. Smith, J. D. 1978. Control of Marasmius oreades fairy rings: a review of methods and new approaches to their elimination. J. Sports Turf Res. Inst. 54:106-114.

32. Smith, J. D. 1980. Is biologic control of Marasmius oreades fairy rings possible? Plant Dis. 64:348-354.

33. Smith, J. D., Jackson, N., and Woolhouse, A. R. 1989. Fungal Diseases of Amenity Turfgrasses. E \& F.N. Spon Ltd., London.

34. Soika, M. D., and Tredway, L. P. 2009. Evaluation of DMI fungicide safety for application to ultradwarf bermudagrass putting greens, 2008. Plant Dis. Manage. Rep. 3:T035.

35. Stiles, C. M., Harmon, P. F., Brecht, M. O., and Datnoff, L. E. 2007. Evaluation of new fungicides and surfactants for the management of fairy ring associated with Lycoperdon sp. in bermudagrass. Appl. Turf. Sci. :1-10.

36. Swartz, D. 1933. Some cultural characters of species of Lycoperdaceae. Am. J. Bot. 22:505-566.

37. Taton, M., Ullman, P., Benveniste, P., and Rahier, A. 1998. Interaction of triazole fungicides and plant growth regulators with microsomal cytochrome P-450-dependent obtusifoliol 14 $\alpha$-methyl demethylase. Pest. Biochem. Physiol. 30:178-189.

38. Tredway, L. P., Butler, E. L., and Soika, M. D. 2007. Evaluation of spring fungicide applications for preventative control of fairy ring, 2006. Plant Dis Manage. Rep. 1:T027.

39. York, C. A., and Canaway, P. M. 2000. Water repellent soils as they occur on UK golf greens. J. Hydrol. 231:126-133. 